\title{
Selective feeding on nutrient-rich particles by gizzard shad Dorosoma cepedianum does not involve mechanical sorting
}

\author{
M. K. Heidman ${ }^{1}$, L. L. Holley ${ }^{1,2}$, R. M. Chambers ${ }^{1}$, S. L. Sanderson ${ }^{1, *}$ \\ ${ }^{1}$ Department of Biology, College of William \& Mary, Williamsburg, Virginia 23187, USA \\ ${ }^{2}$ Present address: Cardno ENTRIX, Houston, Texas 77005, USA
}

\begin{abstract}
Previous field and laboratory studies have concluded that suspension-feeding detritivorous fish such as gizzard shad Dorosoma cepedianum selectively ingest nutrient-rich particles using either mechanical sorting within the oropharyngeal cavity or behavioral selectivity within the environment, but none have distinguished between these hypothesized selection mechanisms. To determine whether mechanical selectivity occurs within the oropharyngeal cavity, gizzard shad were fed particles of standardized size but different carbon and nitrogen content in homogeneous particle suspensions vs. non-homogeneous particle distributions. By comparing foregut and epibranchial organ contents with the particles available in a homogeneous suspension, we demonstrated that the fish did not use mechanical selection for nutrient-rich particles. Previously published hypotheses for intraoral selection of nutrient-rich particles in gizzard shad using crossflow filtration or gustatory receptors were not supported. However, when particles with different nutrient content were allowed to settle in a heterogeneous distribution, the nutrients in the foregut and epibranchial organs were 1.5 times higher than those of particles in the water and 2.5 times higher than those of settled particles $(\mathrm{p} \leq 0.0001)$. As a test of one potential behavioral mechanism of particle selection, disturbance of the sediment-water interface resulted in significantly higher organic carbon ( $p=0.01)$ and nitrogen $(p=0.001)$ within 1 to $2 \mathrm{~cm}$ of the bottom compared to the overlying water and the bottom sediment. Thus, future laboratory and field studies should focus on potential behavioral mechanisms of particle selectivity in detritivorous fish suspension feeding on non-homogeneous distributions of small particles $(\ll<1 \mathrm{~mm})$.
\end{abstract}

KEY WORDS: Suspension feeding - Filter feeding - Feeding selectivity - Particle selection · Detritivory $\cdot$ Dorosoma cepedianum $\cdot$ Crossflow filtration

\section{INTRODUCTION}

Gizzard shad Dorosoma cepedianum (Clupeidae) are omnivorous suspension feeders that use crossflow filtration to extract minute food particles such as detritus, phytoplankton, and zooplankton $(\sim 10 \mu \mathrm{m}$ to $>180 \mu \mathrm{m}$, Drenner et al. 1982, 1984) from the large volumes of water that are sucked into the mouth (Sanderson et al. 2001). Suspension-feeding fish are thought to be relatively non-selective because they feed on particles that are too small to be sensed and engulfed individually (Drenner et al. 1982, Sanderson \& Wassersug 1990, 1993). However, previous field and laboratory studies have concluded that gizzard shad are capable of selecting for detritus particles that are richer in nutrients such as carbon and nitrogen (Mundahl \& Wissing 1988, Smoot 1999, Higgins et al. 2006). Since detritivorous fish can have 
major impacts on nutrient and energy cycling in aquatic environments (Domine et al. 2010, Schaus et al. 2010), their ability to feed selectively is of considerable importance. Here we report results of the first experiments designed to test for mechanical selection of nutrient-rich particles within the oropharyngeal cavity.

Bowen (1983) summarized 2 potential categories of particle selectivity mechanisms in detritivorous fish: (1) behavioral selection by fish for particles in the environment, and (2) mechanical selection for particles within the oropharyngeal cavity due to functional morphological/hydrodynamic processes. Behaviorally, a fish could choose to feed in a more nutrientrich area, e.g. by moving to backwater environments where fine-particulate detritus accumulates (Bowen 1983). Alternatively, based on reports that gizzard shad feeding generates small turbid areas at the sediment-water interface (e.g. Mundahl \& Wissing 1987), Smoot (1999) suggested that gizzard shad could engulf low-density, nutrient-rich particles that remain suspended after denser nutrient-poor particles have settled.

In addition to or instead of behavioral mechanisms for particle selectivity, detritivorous fish could use mechanical selection of particles due to functional morphological features such as epibranchial organs and specializations in gill raker structure (Bowen 1983). For example, Mundahl \& Wissing (1988) suggested that gizzard shad might feed selectively on small nutrient-rich particles using gustatory receptors bordering the epibranchial organs (Schmitz \& Baker 1969, Heinrichs 1982).

A number of previous studies have suggested that the mechanical selection of small food particles $(<<1$ $\mathrm{mm}$ ) could involve hydrodynamic processes inside the oropharyngeal cavity. Using computational fluid dynamic (CFD) simulations and endoscopic experiments with live fish, Sanderson et al. (2001) demonstrated that ngege tilapia Oreochromis esculentus, goldfish Carassius auratus, and gizzard shad Dorosoma cepedianum use crossflow filtration to extract small food particles from water that has entered the oropharyngeal cavity. Based on CFD studies and industrial filtration engineering theory, Sanderson et al. (2001) and Cheer et al. (2012) proposed that the lift and shear experienced by particles at the boundary between the crossflow and the filtrate flow could determine the retention of particles of various size and density inside the oropharyngeal cavity. Smoot \& Findlay (2010a) reported that gizzard shad foreguts contained 8 times more low-density material relative to whole sediment. Consequently, Smoot \& Findlay (2010b) suggested that detritivorous fish could use crossflow filtration to enrich ingesta with low-density microbial-rich particles, resulting in significant increases in the nutrient quality of ingested food.

The intraoral sorting and rejection of large, dense, inorganic particles (e.g. $1 \mathrm{~mm}$ sand grains and $5 \mathrm{~mm}$ gravel) from food by suspension-feeding detritivorous fish has been elucidated (e.g. Callan \& Sanderson 2003) and is not the focus of this study. In addition, the ability of suspension-feeding fish to feed selectively on the basis of particle size has been welldescribed as a function of gill raker gap size distribution (Mummert \& Drenner 1986, Gibson 1988, Friedland et al. 2006). To eliminate particle size as a variable in our experiments, we used a standardized particle size ( 75 to $125 \mu \mathrm{m}$ ).

All previous experiments on particle selectivity have used only a heterogeneous distribution of particles in the environment and have therefore been unable to distinguish between mechanical selectivity and behavioral selectivity. We placed gizzard shad in a controlled laboratory environment to investigate whether selectivity for nutrient-rich detritus particles reported by Mundahl \& Wissing (1988), Higgins et al. (2006), and Smoot \& Findlay (2010a) could have resulted from mechanical sorting inside the oropharyngeal cavity. A novel element of our experiments is that we quantified the particle selectivity of feeding fish in an environment where the particles were mixed homogeneously compared to an environment with a heterogeneous particle distribution.

We tested 2 major hypotheses: (1) when particles of a standardized size with different nutrient (carbon and nitrogen) content are mixed homogeneously in the environment, the nutrient content of particles in the foreguts of gizzard shad will closely match the nutrient content of particles available in the environment, indicating that mechanical selectivity is not occurring; and (2) when particles of a standardized size with different nutrient (carbon and nitrogen) content are distributed heterogeneously in the environment, the nutrient content of particles in the foreguts of gizzard shad will be significantly higher than the environment. Support for these 2 hypotheses would indicate that gizzard shad are using behavioral rather than mechanical selection to ingest particles with higher nutrient content. Alternatively, mechanical particle selection inside the oropharyngeal cavity would be indicated if foregut nutrient content is significantly higher than in the environment when particles with different nutrient content are mixed homogeneously in the environment. 


\section{MATERIALS AND METHODS}

Four types of feeding experiments were conducted in laboratory aquaria. Gizzard shad were dissected immediately after feeding to extract foregut and epibranchial organ contents for comparison with the food particles available in the aquarium. The first experiment used uniform particle size and nutrient content. In the second experiment, food particles of standardized size with different carbon (C) and nitrogen (N) content were mixed continuously throughout the aquarium, creating a homogeneous environment and thereby eliminating the potential for behavioral selection of particles. A third experiment was conducted in which the environment was not mixed homogeneously, thereby allowing food particles to settle and stratify. Foregut and epibranchial organ contents were then compared to samples of food particles from different locations in the nonhomogeneous environment. Finally, to investigate the potential effects of fish movements on the heterogeneity of particle distribution in the environment, a stratification experiment was conducted in which the environment was not mixed homogeneously, fish were not present, and the sediment-water interface was disturbed as suggested by Mundahl \& Wissing (1987) and Smoot (1999).

\section{Gizzard shad collection}

Adult gizzard shad (range 19.0 to $25.5 \mathrm{~cm}$ standard length, SL) were collected from the Virginia coastal plain using electrofishing techniques. Fish were fed daily in $284 \mathrm{l}$ glass aquaria at 19 to $21^{\circ} \mathrm{C}$ and acclimated to laboratory conditions for a minimum of $5 \mathrm{~d}$ prior to experiments.

\section{Food particles}

Commercial food pellets (Big Strike) were used as the high-nutrient food source $(44 \%$ total C, $6 \%$ total N). For the low-nutrient food source, an Ekman Grab sampler was used to collect the top $2 \mathrm{~cm}$ of sediment ( $8 \%$ total $\mathrm{C}, 1 \%$ total $\mathrm{N}$ ) at depths of 3 to $4 \mathrm{~m}$ along the central axis of Lake Matoaka in Williamsburg, VA, in an area where gizzard shad occur. The organic component of sediment in this area of Lake Matoaka is derived primarily from algal production (Pensa \& Chambers 2004). The skeletal densities (mass per unit volume) of the high-nutrient (commercial food pellets) and the low-nutrient (sediment) par- ticles were $1.13 \mathrm{~g} \mathrm{~cm}^{-3}$ and $2.40 \mathrm{~g} \mathrm{~cm}^{-3}$, respectively (Micromeritics Analytical Services, Accupyc II 1340).

Drenner et al. (1984) quantified that interraker spaces in gizzard shad (13.6 to $16.3 \mathrm{~cm} \mathrm{SL}$ ) ranged from 1 to $85 \mu \mathrm{m}$ and that the proportion of microspheres retained by these fish increased as a function of particle size, leveling off at about $60 \mu \mathrm{m}$. Therefore, both the high-nutrient and the low-nutrient food sources were ground and sieved to a size range of 75 to $125 \mu \mathrm{m}$ particles using VWR USA Standard Testing sieves with mesh no. $200(75 \mu \mathrm{m})$ and no. 120 (125 $\mu \mathrm{m})$.

\section{Expt 1: feeding on high-nutrient particles}

A $110 \mathrm{l}$ glass aquarium containing $70 \mathrm{l}$ of water was elevated on wooden blocks $7.5 \mathrm{~cm}$ above the table surface, and 3 stir plates were arranged under the aquarium. Two air stones (15 cm length) were hung on the sides of the aquarium. The spinning of 3 stir bars $(6.5 \mathrm{~cm}$ length, $1 \mathrm{~cm}$ diameter, $300 \mathrm{rpm})$ on the aquarium bottom in conjunction with the 2 air stones mixed particles homogeneously throughout the aquarium without disrupting movements of the fish. The stir bars and air stones created currents to prevent food particles from settling or sorting by density or other physical characteristics. One gizzard shad was transferred from the holding aquaria to the experimental aquarium $48 \mathrm{~h}$ prior to the start of a trial, allowing the fish to acclimate and to empty the foregut of all contents. In preliminary experiments, $24 \mathrm{~h}$ was sufficient for complete gastric emptying. Any observable feces were siphoned from the experimental aquarium prior to each trial.

Each trial $(n=4)$ began by adding to the aquarium $10.00 \mathrm{~g}$ high-nutrient food particles (75 to $125 \mu \mathrm{m}$ ) stirred in $50 \mathrm{ml}$ of water. Fish were allowed to feed for $1 \mathrm{~h}$. To quantify the food available, water samples were taken at 2,30, and 60 min after particles had been added. A plastic tube ( $2.5 \mathrm{~cm}$ diameter) was moved vertically through the water column onto a rubber stopper placed randomly on the bottom of the aquarium, resulting in a water column sample of approx. $125 \mathrm{ml}$.

At the end of each trial, the fish was sacrificed by severing the vertebrae just behind the head, followed by pithing, and was dissected immediately. The foregut was excised within 3 to 5 min and was placed on a clean paper towel. The entire contents of the esophagus and gizzard were extracted using blunt, flat forceps to lift the contents without scraping the foregut lining. Foregut contents were placed in a vial containing deionized water. The entire contents 
of both epibranchial organs, if any, were also collected and placed in a separate vial.

\section{Expt 2: test for mechanical selection}

The nutrient content of the food available to the fish in the aquarium was reduced. Equal amounts (5.00 $\mathrm{g}$ each) of the high-nutrient and low-nutrient food sources were stirred in $50 \mathrm{ml}$ of water and added to the aquarium at the start of each trial $(n=6)$. This 1:1 mixture of high- and low-nutrient particles was used to investigate feeding when equal dry masses of 2 different food sources were mixed homogeneously and maintained in suspension rather than being allowed to settle.

To prevent sediment particles from settling on the aquarium bottom, 4 stir plates were placed under the corners of the aquarium with their associated stir bars (3.75 cm length, $1 \mathrm{~cm}$ diameter) and 2 stir plates were placed under the middle. With a maximum stirring capacity of $1 \mathrm{l}$ each at $300 \mathrm{rpm}$, these stir plates served to gently maintain a suspension of particles in the 701 of aquarium water. Accompanied by the 2 air stones hung on the sides of the aquarium, the 6 stir bars created sufficient water movement to prevent settling and suspend particles homogeneously without disrupting fish movement. A laser particle size analyzer (laser in situ scattering and transmissometry, LISST-100X, Sequoia Scientific) was used to quantify the effects of stirring on the sizes of the high-nutrient and low-nutrient particles. All other methods were performed as in Expt 1.

\section{Expt 3: test for behavioral selection}

To investigate how particle ingestion by gizzard shad is affected by heterogeneity in the environmental distribution of food particles with different nutrient content, all stir bars were removed. Equal amounts (10.00 g each) of the high-nutrient and lownutrient food sources were stirred in $50 \mathrm{ml}$ of water and added to the aquarium at the start of each trial $(n=11)$. Since particles tended to settle quickly in the absence of stirring, a total of $20.00 \mathrm{~g}$ of particles was used to ensure that sufficient particles were available for feeding. Thirty minutes after the particles had been introduced, the methods described previously were used to take a water column sample with minimal disturbance. Immediately after the water sampling, the particles that had settled on the aquarium bottom were sampled using a pipette to remove all particles from the glass surface (approximately $2 \mathrm{ml}$ of particles) in an area selected randomly and approx. equidistant from the 2 air stones.

The foregut contents of each gizzard shad were divided into 2 samples by taking half from the esophagus and half from the gizzard to compose each sample. One sample from each trial was used to measure total $\mathrm{C}$ and total $\mathrm{N}$ content and the other sample was used for organic $\mathrm{C}$ analysis. If total foregut content was $\leq 5.00 \mathrm{mg}$, the foregut contents were not divided and only total $\mathrm{C}$ and total $\mathrm{N}$ analyses were performed. Only 1 fish had epibranchial organ contents with sufficient mass to split for organic C analysis. All other methods were performed as in Expt 2.

\section{Expt 4: stratification and disturbance of sediment-water interface}

To investigate stratification and the effects of disturbance of the sediment-water interface on the heterogeneity of particle distribution, the methods of Expt 3 were used with the exception that no fish were present $(\mathrm{n}=6)$. The aquarium was labeled externally with 3 horizontal sections, each $10.3 \mathrm{~cm}$ in height. A 1:1 ratio of high-nutrient and low-nutrient particles (total $20.00 \mathrm{~g}$ ) were stirred in $50 \mathrm{ml}$ of water and added to the aquarium. After the particles had settled for $30 \mathrm{~min}$, two $125 \mathrm{ml}$ samples were siphoned from the center of each of the top, middle, and lower horizontal sections using plastic tubing $(3.0 \mathrm{~mm}$ internal diameter). Two vertical water samples and 2 samples from the aquarium bottom were then collected as in Expt 3. Immediately thereafter, two $125 \mathrm{ml}$ water samples were siphoned 1 to $2 \mathrm{~cm}$ above the aquarium bottom using the plastic tubing while disturbing the sediment-water interface by moving the tip of the tubing slightly from side-to-side to generate water currents that lifted some particles off the bottom ('slight disturbance'). Two additional $125 \mathrm{ml}$ water samples were then siphoned from directly above the aquarium bottom while moving the tip of the tubing more vigorously to generate water currents of higher speeds ('stronger disturbance') that lifted more but not all particles off the bottom. One sample from each location was used for total $\mathrm{C}$ and total $\mathrm{N}$ analyses and the other was used for organic $\mathrm{C}$ analysis.

\section{Elemental analysis}

All samples from the feeding experiments and the stratification experiment were filtered onto tared 
$25 \mathrm{~mm}$ glass Whatman GF/C microfiber filters for C and $\mathrm{N}$ analyses. Filtered samples were stored in the drying oven at $60^{\circ} \mathrm{C}$ for at least $24 \mathrm{~h}$ before dry mass was measured to the nearest $0.01 \mathrm{mg}$ on a Perkin Elmer AD 6 microbalance. A Perkin-Elmer 2400 Analyzer was used to determine the \% total $\mathrm{C}$ and $\mathrm{N}$ by dry mass of each of the samples.

To quantify organic $\mathrm{C}$ and organic $\mathrm{N}$, samples were filtered using the method described above and placed in a muffle furnace at $450^{\circ} \mathrm{C}$ for $3 \mathrm{~h}$. Using a Perkin-Elmer 2400 Analyzer, the inorganic C and inorganic $\mathrm{N}$ that remained were quantified and subtracted from the total $\mathrm{C}$ and total $\mathrm{N}$ values, respectively, to calculate the organic $\mathrm{C}$ and organic $\mathrm{N}$ content for each sample. Total $\mathrm{N}$ is reported because inorganic $\mathrm{N}$ accounted for less than $5 \%$ of total $\mathrm{N}$.

\section{Selectivity indices}

For Expts 1 to 3, C and N selectivity indices were calculated for each gizzard shad foregut. To calculate each selectivity index, the \% nutrient per gram dry mass of the foregut content was divided by the $\%$ nutrient per gram dry mass of the corresponding water sample (Mundahl \& Wissing 1988, Higgins et al. 2006). For each trial, the water value used in the selectivity index was calculated by averaging the $\%$ nutrient per gram dry mass of the 3 vertical samples taken during the trial at 2, 30, and $60 \mathrm{~min}$. When epibranchial organ contents were available, a selectivity index was also calculated for the epibranchial organs. For Expt 3, a selectivity index was calculated for the foregut content with respect to the water sample and for the foregut content with respect to the sample from the aquarium bottom.

\section{Statistical analysis}

Repeated measures ANOVA was used in Expts 1 and 2 for both $\mathrm{C}$ and $\mathrm{N}$ to test for significant differences between the vertical water column samples from the aquarium taken at 2,30, and $60 \mathrm{~min}$. Oneway ANOVAs were then performed to test for significant differences between water column, foregut, and epibranchial organ values of $\mathrm{C}$ and $\mathrm{N}$ for Expts 1 through 3 and to test for significant differences between water and bottom values for Expt 4. If significant differences were found using 1-way ANOVA, a Tukey-Kramer HSD test was used to test each of the pairs of variables $(\alpha=0.05)$. A sequential Bonferroni correction was used to account for the number of statistical tests performed (Rice 1989).

\section{RESULTS}

\section{Gizzard shad behavior}

Fish swimming behavior was characterized during all experiments by constant swimming in full loops, primarily in the lower half of the aquarium. Feeding was characterized by buccal movements during swimming. Fish did not suck particles directly off of the bottom of the aquarium, with an exception observed during Expt 3 when 1 fish sucked particles directly from the aquarium bottom a few times in addition to feeding in the water column.

\section{Expt 1: feeding on high-nutrient particles}

When gizzard shad were fed homogeneous suspensions of high-nutrient particles, the \% dry mass of $\mathrm{C}$ and of $\mathrm{N}$ in the foregut contents and in the epibranchial organ contents were not significantly different from those quantified in the water column where the fish were feeding (1-way ANOVA, $p$ > 0.05, Table 1). Selectivity indices were approx. 1.0.

\section{Expt 2: test for mechanical selection}

When gizzard shad were fed a homogeneous 1:1 suspension of low-nutrient:high-nutrient particles, there were no significant differences in the nutrient composition of the water column samples collected 2, 30 and 60 min after the addition of particles to the aquarium (repeated measures ANOVA, p > 0.05). Therefore, the 3 water column $\mathrm{N}$ values and the 3 water column $\mathrm{C}$ values were averaged within each trial and the means were used as the vertical water column values in subsequent statistical analyses. This stability of the nutrient levels in the water indicates that the stir plates maintained a homogeneous suspension of particles in the aquarium. This result also demonstrates that the feeding of the gizzard shad did not have a detectable impact on the composition of the particle suspension during these experiments and that the food source available to the fish was effectively constant during the course of these experiments. The laser particle size analyzer (LISST-100X) confirmed that the mean size of the high-nutrient and low-nutrient particles varied 
Table 1. Dorosoma cepedianum. Feeding of gizzard shad in Expt 1 on a homogeneous suspension of high-nutrient particles and in Expt 2 on a homogeneous 1:1 suspension of low-nutrient:high-nutrient particles. Mean $\pm \mathrm{SE}(\mathrm{n})$ for $\%$ total C and \% total $\mathrm{N}$ in the water column, foregut, and epibranchial organs. Mean $\pm \mathrm{SE}$ (n) for selectivity indices in the foregut and epibranchial organs (\% nutrient per gram dry mass foregut content or epibranchial organ content divided by \% nutrient per gram dry mass of corresponding water sample)

\begin{tabular}{|c|c|c|c|c|c|c|}
\hline \multirow{2}{*}{$\begin{array}{l}\text { Nutrient } \\
\text { content (\%) }\end{array}$} & \multirow{2}{*}{ Water column } & \multicolumn{2}{|c|}{ Foregut } & \multicolumn{2}{|c|}{ _ Epibranchials } & \multirow{2}{*}{$\mathrm{p}$} \\
\hline & & Content & Selectivity index & Content & Selectivity index & \\
\hline \multicolumn{7}{|l|}{ Expt 1} \\
\hline Total C & $43.58 \pm 0.55(4)$ & $39.99 \pm 1.60(4)$ & $0.92 \pm 0.04(4)$ & $42.41(1)$ & $0.97(1)$ & 0.18 \\
\hline Total N & $5.97 \pm 0.08(4)$ & $6.45 \pm 0.24(4)$ & $1.08 \pm 0.01(4)$ & $6.49(1)$ & $1.09(1)$ & 0.21 \\
\hline \multicolumn{7}{|l|}{ Expt 2} \\
\hline Total C & $28.44 \pm 0.26(6)$ & $26.95 \pm 1.13(6)$ & $0.95 \pm 0.04(6)$ & $28.19 \pm 2.16(6)$ & $0.99 \pm 0.07(6)$ & 0.73 \\
\hline Total N & $3.81 \pm 0.07(6)$ & $3.99 \pm 0.24(6)$ & $1.05 \pm 0.05(6)$ & $3.78 \pm 0.24(6)$ & $0.99 \pm 0.06(6)$ & 0.73 \\
\hline
\end{tabular}

by less than 6 to $8 \%$ over the time course of the experiments.

The \% dry mass of $\mathrm{C}$ and of $\mathrm{N}$ in the foregut contents and in the epibranchial organ contents were not significantly different from those quantified in the water column where the fish were feeding (1-way ANOVA, $p>0.05$, Table 1). Selectivity indices were approx. 1.0.

\section{Expt 3: test for behavioral selection}

When gizzard shad were fed a 1:1 ratio of lownutrient:high-nutrient particles with no stirring, particle settling created a non-homogeneous distribution of particles in the aquarium. In contrast to the results of Expts 1 and 2, the \% total $\mathrm{C}$ and \% total $\mathrm{N}$ of foregut contents and epibranchial organ contents
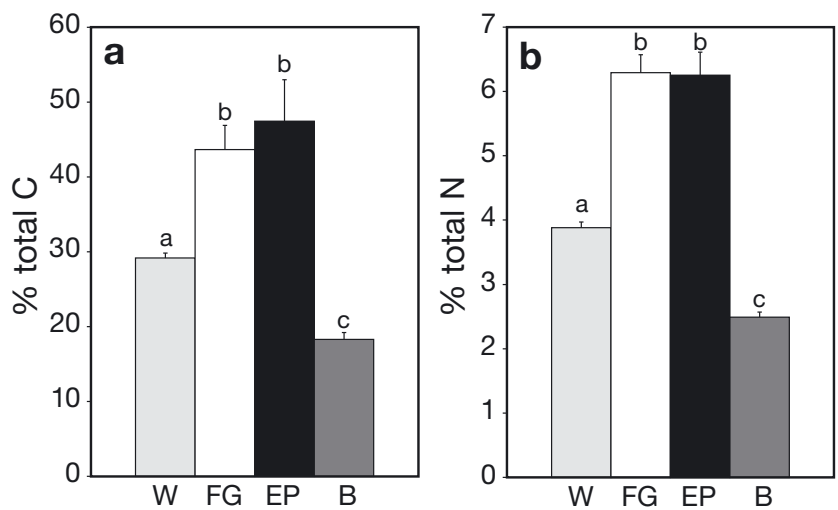

Fig. 1. Dorosoma cepedianum. Mean $\pm \mathrm{SE}(\mathrm{a}) \%$ total $\mathrm{C}$ and (b) \% total $\mathrm{N}$ in the water column $(\mathrm{W} ; \mathrm{n}=11)$, foregut $(\mathrm{FG}$; $\mathrm{n}=10)$, epibranchial organs $(\mathrm{EP}, \mathrm{n}=7)$, and bottom of the aquarium $(B ; n=11)$ for a 1:1 ratio of non-homogeneous lownutrient:high-nutrient particles with no stirring of the aquarium during Expt 3. Different letters show significant differences (1-way ANOVA, Tukey-Kramer post hoc pair-wise comparisons, $\mathrm{p} \leq 0.05$ ) were significantly higher than the nutrient content of particles in the water or on the aquarium bottom (1way ANOVA, $p \leq 0.0001$, Table 2, Fig. 1). For both $\%$ $\mathrm{C}$ and $\% \mathrm{~N}$, the only non-significant pair-wise comparisons were between foregut and epibranchial organs (Fig. 1). Selectivity indices were approx. 1.5 with respect to the water and approx. 2.5 with respect to the aquarium bottom (Table 2).

One-way ANOVA was also used to compare \% organic $\mathrm{C}$ in the water column, aquarium bottom, and foregut samples ( $\mathrm{p} \leq 0.0001$, Table 2, Fig. 2). The single epibranchial sample was not included in this analysis. In a Tukey-Kramer HSD test, all pairs were significantly different (Fig. 2). Selectivity indices for organic C were similar to those for total C (Table 2).

\section{Expt 4: stratification and disturbance of sediment-water interface}

When a 1:1 ratio of low-nutrient:high-nutrient particles was used with no stirring of the aquarium and no fish present, there were no significant differences in \% total $\mathrm{C}$, \% organic $\mathrm{C}$, or \% total $\mathrm{N}$ in horizontal water samples taken from the top, middle, or lower thirds of the aquarium (Table 3 ).

One-way ANOVAs compared nutrient contents of samples taken from the entire vertical water column, from the undisturbed bottom of the aquarium, from directly above the aquarium bottom during slight disturbance of the sediment-water interface, and from directly above the aquarium bottom during stronger disturbance of the sediment-water interface. The results for $\%$ total $\mathrm{C}$, \% organic $\mathrm{C}$, and $\%$ total $\mathrm{N}$ were significant $(p=0.005, p=0.01$, and $p=0.001$, respectively). The \% total C and \% organic $\mathrm{C}$ were significantly higher in the samples taken during strong disturbance of the sediment-water interface compared 


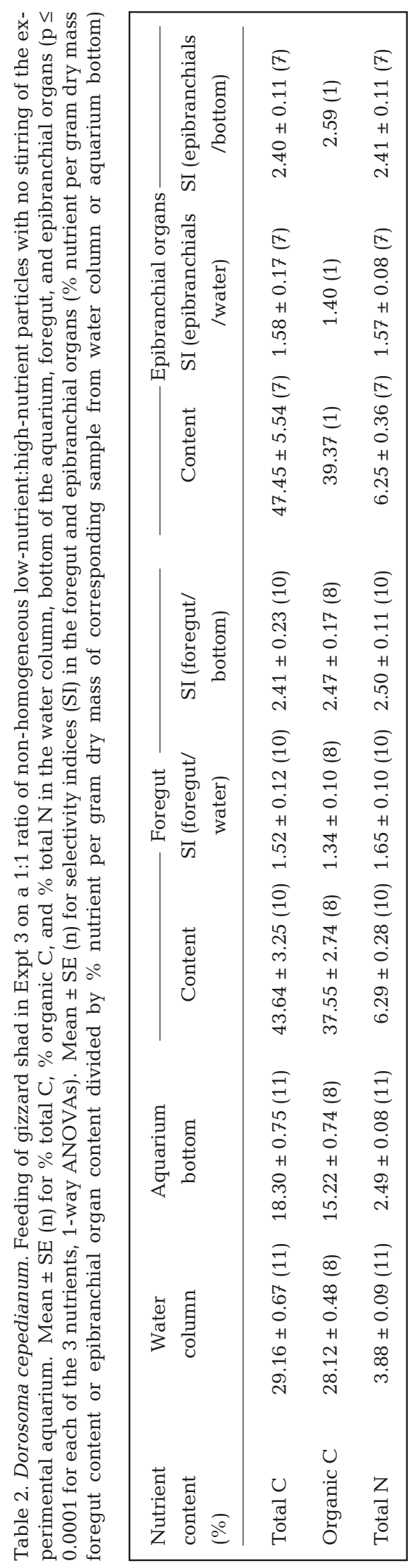

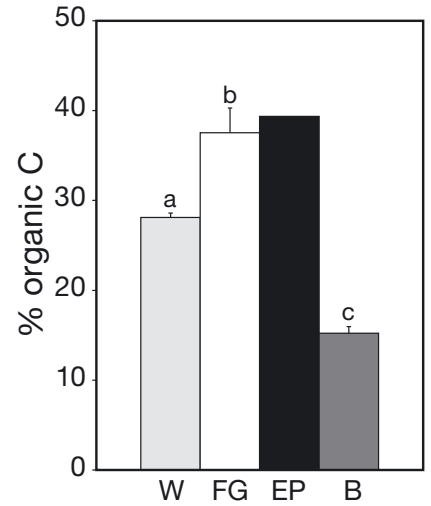

Fig. 2. Dorosoma cepedianum. Mean $\pm \mathrm{SE} \%$ organic $\mathrm{C}$ in the water column $(\mathrm{W} ; \mathrm{n}=8)$, foregut $\left(\mathrm{FG}_{;} \mathrm{n}=8\right)$, epibranchial organs ( $E P ; n=1)$, and bottom of the aquarium $(B ; n=8)$ for a 1:1 ratio of non-homogeneous low-nutrient:high-nutrient particles with no stirring of the aquarium during Expt 3. Different letters show significant differences (1-way ANOVA, Tukey-Kramer post hoc pair-wise comparisons, $\mathrm{p} \leq 0.05$ )

to vertical samples from the entire water column and compared to samples taken from the aquarium bottom (Tukey-Kramer HSD tests, $\mathrm{p} \leq 0.05$, Fig. 3a,b). The $\%$ total $\mathrm{N}$ was significantly higher in the samples taken during strong disturbance of the sedimentwater interface compared to the samples taken from the water column, from the aquarium bottom, and during slight disturbance of the sediment-water interface (Tukey-Kramer HSD test, $\mathrm{p} \leq 0.05$, Fig. 3c).

To calculate selectivity indices, the nutrient content in the water samples siphoned directly above the aquarium bottom during strong disturbance of the sediment-water interface were compared to vertical samples from the entire water column and to samples from the aquarium bottom (Table 4, Fig. 3). These selectivity indices for total $\mathrm{C}$, organic $\mathrm{C}$, and total $\mathrm{N}$ were greater than 1.0. In contrast, the selectivity index for inorganic $\mathrm{C}$ in the water directly above the aquarium bottom compared to the entire water col-

Table 3. Stratification experiment (Expt 4) using a 1:1 ratio of low-nutrient:high-nutrient particles with no stirring of the aquarium and no fish present. Mean $\pm \mathrm{SE}(\mathrm{n}=6)$ for $\%$ total $\mathrm{C}, \%$ organic $\mathrm{C}$, and \% total $\mathrm{N}$ in water sampled from the top, middle, and lower thirds of the aquarium

\begin{tabular}{|c|c|c|c|c|}
\hline \multirow{2}{*}{$\begin{array}{l}\text { Nutrient } \\
\text { content } \\
(\%)\end{array}$} & \multicolumn{3}{|c|}{ Location in aquarium } & \multirow{2}{*}{$\mathrm{p}$} \\
\hline & $\begin{array}{l}\text { Top } \\
\text { third }\end{array}$ & $\begin{array}{c}\text { Middle } \\
\text { third }\end{array}$ & $\begin{array}{c}\text { Lower } \\
\text { third }\end{array}$ & \\
\hline Total C & $24.82 \pm 0.83$ & $25.44 \pm 0.58$ & $26.32 \pm 1.32$ & 0.55 \\
\hline Organic C & $23.30 \pm 0.81$ & $24.08 \pm 0.60$ & $25.12 \pm 1.38$ & 0.44 \\
\hline Total N & $3.25 \pm 0.33$ & $3.18 \pm 0.08$ & $3.27 \pm 0.16$ & 0.96 \\
\hline
\end{tabular}



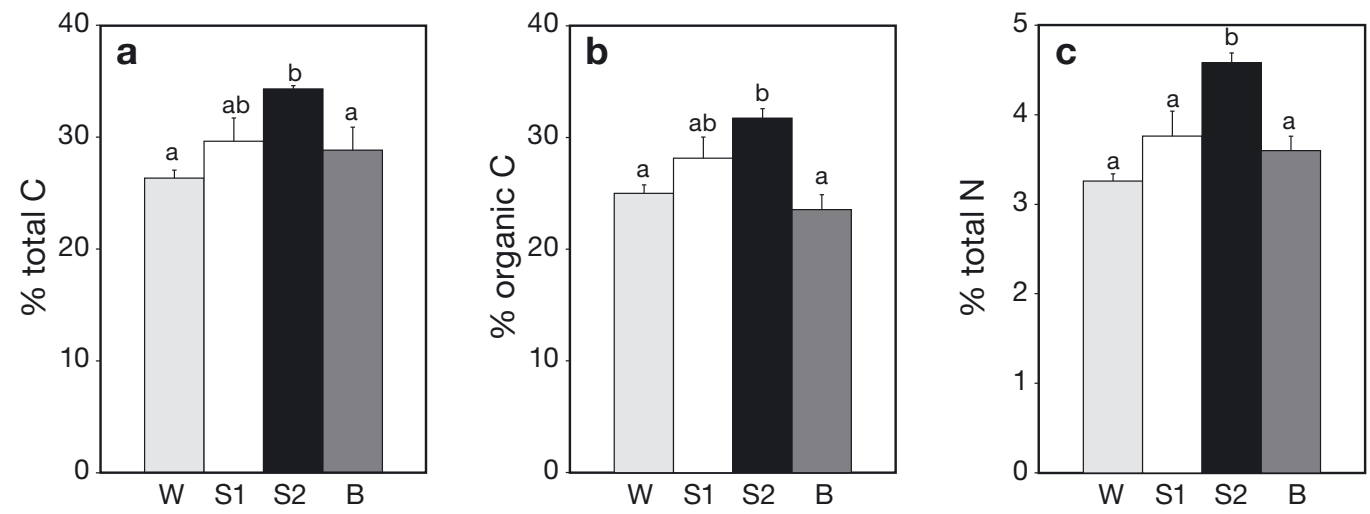

Fig. 3. Dorosoma cepedianum. Mean $\pm \mathrm{SE}(\mathrm{n}=6)(\mathrm{a}) \%$ total $\mathrm{C}$, (b) \% organic $\mathrm{C}$, and (c) \% total $\mathrm{N}$ in samples taken during Expt 4 from the entire vertical water column (W), from directly above the bottom of the aquarium during weak disturbance of the sediment-water interface (S1) and during strong disturbance of the sediment-water interface $(\mathrm{S} 2, \mathrm{n}=5)$, and from the undisturbed aquarium bottom (B) for a 1:1 ratio of low-nutrient:high-nutrient particles with no stirring of the aquarium and no fish present. Different letters show significant differences (1-way ANOVA, Tukey-Kramer post hoc pair-wise comparisons, p $\leq$ 0.05)

Table 4 . Selectivity indices calculated by dividing the \% nutrient values from strong disturbance of the sediment-water interface in Expt 4 (S2 in Fig. 3) by the water column values (W in Fig. 3) or the aquarium bottom values (B in Fig. 3) for total, inorganic, and organic $\mathrm{C}$ and for total N. Mean $\pm \mathrm{SE}(\mathrm{n}=5)$

\begin{tabular}{|lcc|}
\hline \multirow{2}{*}{ Nutrients } & \multicolumn{2}{c|}{ Selectivity indices } \\
\cline { 2 - 3 } & Water column & Aquarium bottom \\
\hline Total C & $1.34 \pm 0.05$ & $1.22 \pm 0.07$ \\
Inorganic C & $1.96 \pm 0.21$ & $0.52 \pm 0.09$ \\
Organic C & $1.31 \pm 0.05$ & $1.43 \pm 0.18$ \\
Total N & $1.43 \pm 0.05$ & $1.31 \pm 0.06$ \\
\hline
\end{tabular}

umn was almost 2.0 and the selectivity index for inorganic $\mathrm{C}$ in the water directly above the bottom compared to the sample from the bottom was 0.5 (Table 4).

\section{DISCUSSION}

Detritus, broadly defined as non-living organic matter and associated heterotrophic and autotrophic microorganisms, is readily available and may accumulate in large quantities in aquatic environments (Bowen 1979, Smoot 1999). However, detritus has low nutrient content and the growth rate and adult body condition of detritivorous fish can be limited by nutrient availability in their food (Bowen 1983, Mundahl \& Wissing 1987, Ahlgren 1990, Bowen et al. 1995, Higgins et al. 2006). Detritivorous fish such as gizzard shad are an important energy link to higher trophic levels, particularly piscivorous fish and birds. In addition, through excretion in the water column, gizzard shad make nutrients available to primary producers such as phytoplankton (Schaus et al. 1997, Vanni 2002, Vanni et al. 2005, Domine et al. 2010, Schaus et al. 2010). Thus, the ability of detritivorous fish to selectively ingest nutrient-rich particles has substantial ecological and physiological importance.

\section{Feeding selectivity}

Recent field and laboratory studies using non-homogeneous food sources have quantified that nutrient content in the foregut of gizzard shad is significantly higher than that in the inferred food source. The foregut contents of adult gizzard shad from 3 Ohio reservoirs had significantly higher percentages of nitrogen, organic carbon, and phosphorus than found in the top $2 \mathrm{~cm}$ of sediment from shallow pools in the upstream regions (Higgins et al. 2006). Gizzard shad foregut contents in Acton Lake, Ohio also had significantly higher percentages of nitrogen, carbon, and total organic matter than detritus collected over a period of 18 to $20 \mathrm{~h}$ in sediment traps (Mundahl \& Wissing 1988). In the laboratory, when age- 0 and adult gizzard shad were fed a low-nutrient diet consisting of a 5:1 ratio of surface sediment and aufwuchs that had settled on the bottom of a Living Stream system, nutrient content of the foregut was significantly higher than this food source (Mundahl \& Wissing 1988). These findings led to the conclusion that gizzard shad are selective for nutrient-rich particles (Mundahl \& Wissing 1988, Higgins et al. 2006), but mechanisms for this se- 
lective ingestion of nutrient-rich particles had not been determined.

\section{Mechanisms for selection of nutrient-rich particles}

During industrial crossflow filtration, lift and shear act to retain certain particles in the mainstream flow while other particles are lost through filter pores or are trapped on the filter surface (Chellam \& Weisner 1997, Sethi \& Weisner 1997, Sutherland 2008). Smoot \& Findlay (2010b) proposed that crossflow filtration could be responsible for the selective retention of low-density nutrient-rich particles by detritivorous fish such as gizzard shad.

The homogeneous suspension of low-nutrient and high-nutrient particles in our study has provided the first test of the hypothesis that detritivorous fish use functional morphological/hydrodynamic processes inside the oropharyngeal cavity to select for nutrientrich particles. Although gizzard shad use morphological features such as gill rakers and epibranchial organs to retain particles during crossflow filtration (Sanderson et al. 2001), the gizzard shad in our experiments did not use mechanical sorting to select particles of higher nutrient content inside the oropharyngeal cavity (Table 1).

In contrast, our experiments with a non-homogeneous food source were consistent with previous field and laboratory studies demonstrating significant gizzard shad selectivity for nutrient-rich particles. When particles with different nutrient content were allowed to settle and distribute heterogeneously in the aquarium, the nutrients in the foregut and epibranchial organs were approximately 1.5 times higher than those of particles in the water and 2.5 times higher than those of particles on the aquarium bottom ( $p \leq 0.0001$, Table 2, Figs. $1 \& 2$ ). Given that the gizzard shad did not use intraoral mechanical mechanisms to select for nutrient-rich particles (Table 1), the only remaining hypothesis in the literature is that behavioral mechanisms could be responsible for gizzard shad selectivity for nutrient-rich particles in the non-homogeneous environment, during our experiments and during the previously published studies mentioned above.

Non-homogeneous distribution of particles provides the opportunity for behavioral selection of particles by detritivorous fish. Fish that ingest benthic detritus may choose to feed in locations with more nutrient-rich particles (Bowen 1983). For example, the speed of water flow affects the sizes of particles that settle out of suspension. Once entrained, small particles remain suspended at lower flow speeds than do larger particles. Consequently, areas with slow currents can accumulate more fine particulate detritus with higher organic content (Bowen 1983). In addition, fish can disturb the sediment-water interface, causing particles to enter the overlying water column, and can then allow denser, nutrient-poor particles to settle while engulfing nutrient-rich particles that are still suspended (Smoot 1999).

When gizzard shad were fed a 1:1 ratio of lownutrient:high-nutrient particles with no stirring of the experimental aquarium in Expt 3, the particles were distributed non-homogeneously in the aquarium due to settling, with more nutrient-rich particles remaining suspended in the water rather than sinking to the aquarium bottom (Table 2, Figs. 1 \& 2). The fish in our experiments generally swam and suspension-fed in the lower half of the water column rather than using suction feeding to engulf particles that were settled on the aquarium bottom. This feeding behavior is consistent with the higher selectivity indices for foregut/bottom comparisons in Expt 3 (approx. 2.5) relative to the selectivity indices for foregut/water column comparisons (approx. 1.5, Table 2). However, gizzard shad foreguts and epibranchial organs contained significantly higher \% C and \% N than were present in vertical samples of the entire water column, demonstrating that the higher nutrient content of the particles in the entire water column could not fully account for the significant feeding selectivity quantified in the foregut and epibranchial organ contents. Furthermore, since horizontal water samples taken from the top, middle, and lower thirds of the aquarium during Expt 4 were not significantly different in \% C or \% N (Table 3), the gizzard shad could not have selected for more nutrient-rich particles by suspension feeding preferentially in water from the top, middle, or lower thirds of the aquarium.

Our disturbance of the sediment-water interface during Expt 4 illustrates a potential behavioral mechanism of selectivity for more nutrient-rich particles (Fig. 3). During this experiment using a 1:1 ratio of low-nutrient:high-nutrient particles with no stirring of the aquarium and no fish present, the darkercolored, denser, low-nutrient particles $\left(2.40 \mathrm{~g} \mathrm{~cm}^{-3}\right)$ settled first and were then covered by the lightercolored, less dense, high-nutrient particles (1.13 g $\mathrm{cm}^{-3}$ ). Following strong disturbance of the sedimentwater interface in Expt 4, nutrient content of the water sampled 1 to $2 \mathrm{~cm}$ above the bottom was significantly higher than nutrient content in vertical samples of the entire water column or samples from the aquarium bottom (Fig. 3). 
The selectivity indices for organic $\mathrm{C}$ and total $\mathrm{N}$ in Table 4 and the data in Fig. 3 establish that strong disturbance of the sediment-water interface created a region 1 to $2 \mathrm{~cm}$ above the bottom of the aquarium that was enriched in nutrient content relative to the entire vertical water column or the aquarium bottom. Low-density, nutrient-rich particles were resuspended more readily than denser inorganic particles. The selectivity indices of 1.3 to 1.4 for $\mathrm{C}$ and $\mathrm{N}$ comparing the area directly above the disturbed sediment vs. the entire vertical water column (Table 4) were similar to the selectivity indices of 1.3 to 1.6 comparing the contents of the foregut and the epibranchial organs vs. the entire vertical water column in the non-homogeneous Expt 3 (Table 2). In support of Smoot's (1999) hypothesis, these results demonstrate that gizzard shad could use behavioral mechanisms of particle selectivity by swimming and feeding directly above the bottom to re-suspend and ingest a higher proportion of low-density particles with greater nutrient content.

Fish movement could re-suspend less dense, more nutrient-rich particles and leave more of the denser, nutrient-poor particles on the bottom. This theory is supported by the selectivity indices calculated for $\%$ inorganic C, \% organic C, and \% total $\mathrm{N}$ in Table 4. Strong disturbance of the sediment-water interface in Experiment 4 resulted in high organic $\mathrm{C}$ and high total $\mathrm{N}$ in the water directly above the bottom compared to the entire vertical water column and the bottom of the aquarium. The \% inorganic $\mathrm{C}$ in the water sampled directly above the aquarium bottom during the strong disturbance was also high compared to the $\%$ inorganic $\mathrm{C}$ in the entire vertical water column ( $\sim 2.6 \%$ vs. $\sim 1.3 \%$, respectively), and the corresponding mean selectivity index for inorganic $\mathrm{C}$ was high (1.96) (Table 4). This high selectivity index indicates that strong disturbance of the sediment-water interface did re-suspend inorganic particles. However, when the \% inorganic $\mathrm{C}$ in the water sampled directly above the aquarium bottom during the strong disturbance ( $2.6 \%$ inorganic $C)$ was compared to the \% inorganic $\mathrm{C}$ sampled from the bottom of the aquarium $(\sim 5.3 \%$ inorganic $C)$, the mean selectivity index was low (0.52), indicating that the \% dry mass of inorganic $\mathrm{C}$ particles was still twice as high on the bottom of the aquarium compared to the water sampled directly above the aquarium bottom during strong disturbance of the sediment-water interface. These data demonstrate the need for future studies that quantify the nutrients available to detritivorous fish in their microhabitats as a result of their feeding and swimming behavior.

\section{CONCLUSIONS}

The novel use of a homogeneous environment in our experiments allowed intraoral mechanical selection to be tested independently of behavioral particle selection. When gizzard shad were fed a homogeneous suspension of particles with different nutrient content and standardized size, there was no evidence that gizzard shad have the ability to mechanically select nutrient-rich particles within the oropharyngeal cavity using functional morphological/hydrodynamic processes. However, when fish fed on a nonhomogeneous distribution of particles with different nutrient content and standardized size, fish foregut and epibranchial organ contents were significantly higher in \% C and \% $\mathrm{N}$ by dry mass compared to particles suspended in the water column and compared to particles settled on the bottom of the aquarium.

Our experiments demonstrated that a nonhomogeneous distribution of particles created microhabitats in which gizzard shad could behaviorally select for nutrient-rich particles. Disturbance of the sediment-water interface caused the water directly above the bottom of the aquarium to be richer in organic $\mathrm{C}$ and total $\mathrm{N}$ compared to the entire water column and the bottom.

The absence of mechanical selection for nutrientrich particles by gizzard shad in these experiments emphasizes the value of future laboratory and mesocosm studies that provide opportunities for the quantification and manipulation of detritivorous fish feeding behavior. In addition, theoretical and experimental studies of crossflow filtration are needed to quantify the particle sizes and densities that may affect particle retention by suspension-feeding and detritivorous fish (Sanderson et al. 2001, Cheer et al. 2012).

Acknowledgements. We thank G. Capelli, P. Heideman, G. Gilchrist, M. Leu, H. Murphy, and D. Shakes for advice on experimental and statistical design, C. Friedrichs and G. Cartwright for use of the LISST-100X, F. Armstrong and T. Meier for assistance with experimental set-up, and S. Hermann and M. Blommel from the Virginia Department of Game and Inland Fisheries for fish collection. Approved research protocols IACUC-2010-03-10-6438-slsand and IACUC-2008-02-01-5111-slsand.

\section{LITERATURE CITED}

Ahlgren MO (1990) Diet selection and the contribution of detritus to the diet of the juvenile white sucker (Catostomus commersoni). Can J Fish Aquat Sci 47:41-48

$>$ Bowen SH (1979) A nutritional constraint in detritivory by fishes: the stunted population of Sarotherodon mossambicus in Lake Sibaya, South Africa. Ecol Monogr 49:17-31 
Bowen SH (1983) Detritivory in neotropical fish communities. Environ Biol Fishes 9:137-144

Bowen SH, Lutz EV, Ahlgren MO (1995) Dietary protein and energy as determinants of food quality: trophic strategies compared. Ecology 76:899-907

Callan WT, Sanderson SL (2003) Feeding mechanisms in carp: crossflow filtration, palatal protrusions and flow reversals. J Exp Biol 206:883-892

Cheer A, Cheung S, Hung TC, Piedrahita RH, Sanderson SL (2012) Computational fluid dynamics of fish gill rakers during crossflow filtration. Bull Math Biol 74:981-1000

Chellam S, Weisner MR (1997) Particle back-transport and permeate flux behavior in crossflow membrane filters. Environ Sci Technol 31:819-824

Domine LM, Vanni MJ, Renwick WH (2010) New and regenerated primary production in a productive reservoir ecosystem. Can J Fish Aquat Sci 67:278-287

Drenner RW, Mummert JR, O'Brien WJ (1982) Filter-feeding rates of gizzard shad. Trans Am Fish Soc 111:210-215

> Drenner RW, Mummert JR, deNoyelles F, Kettle D (1984) Selective particle ingestion by a filter-feeding fish and its impact on phytoplankton community structure. Limnol Oceanogr 29:941-948

Friedland KD, Ahrenholz DW, Smith JW, Manning M, Ryan J (2006) Sieving functional morphology of the gill raker feeding apparatus of Atlantic menhaden. J Exp Zool A 305A:974-985

> Gibson RN (1988) Development, morphometry and particle retention capability of the gill rakers in the herring, Clupea harengus L. J Fish Biol 32:949-962

Heinrichs SM (1982) Ontogenetic changes in the digestive tract of the larval gizzard shad, Dorosoma cepedianum. Trans Am Microsc Soc 101:262-275

Higgins KA, Vanni MJ, González MJ (2006) Detritivory and the stoichiometry of nutrient cycling by a dominant fish species in lakes of varying productivity. Oikos 114: $419-430$

Mummert JR, Drenner RW (1986) Effect of fish size on the filtering efficiency and selective particle ingestion of a filter-feeding clupeid. Trans Am Fish Soc 115:522-528

Mundahl ND, Wissing TE (1987) Nutritional importance of detritivory in the growth and condition of gizzard shad in an Ohio reservoir. Environ Biol Fishes 20:129-142

Mundahl ND, Wissing TE (1988) Selection and digestive efficiencies of gizzard shad feeding on natural detritus and two laboratory diets. Trans Am Fish Soc 117: $480-487$

Editorial responsibility: J. Rudi Strickler, Milwaukee, Wisconsin, USA
Pensa MA, Chambers RM (2004) Trophic transition in a lake on the Virginia coastal plain. J Environ Qual 33:576-580

Rice WR (1989) Analyzing tables of statistical tests. Evolution 43:223-225

> Sanderson SL, Wassersug R (1990) Suspension-feeding vertebrates. Sci Am 262:96-101

Sanderson SL, Wassersug R (1993) Convergent and alternative designs for vertebrate suspension feeding. In: Hanken J, Hall BK (eds) The skull, Vol 3: functional and evolutionary mechanisms. University of Chicago Press, Chicago, IL, p 37-112

Sanderson SL, Cheer AY, Goodrich JS, Graziano JD, Callan WT (2001) Crossflow filtration in suspension-feeding fishes. Nature 412:439-441

Schaus MH, Vanni MJ, Wissing TE, Bremigan MT, Garvey JE, Stein RA (1997) Nitrogen and phosphorus excretion by detritivorous gizzard shad in a reservoir ecosystem. Limnol Oceanogr 42:1386-1397

Schaus MH, Godwin W, Battoe L, Coveney M and others (2010) Impact of the removal of gizzard shad (Dorosoma cepedianum) on nutrient cycles in Lake Apopka, Florida. Freshw Biol 55:2401-2413

> Schmitz EH, Baker CD (1969) Digestive anatomy of the gizzard shad, Dorosoma cepedianum and the threadfin shad, D. petenense. Trans Am Microsc Soc 88:525-546

Sethi S, Weisner MR (1997) Modeling of transient permeate flux in cross-flow membrane filtration incorporating multiple particle transport mechanisms. J Membr Sci 136: 191-205

Smoot JC (1999) A field study of sedimentary microbiota as food for detritivorous gizzard shad, Dorosoma cepedianum, in Acton Lake: a biomarker approach. $\mathrm{PhD}$ dissertation, Miami University, Oxford, $\mathrm{OH}$

Smoot JC, Findlay RH (2010a) Caloric needs of detritivorous gizzard shad Dorosoma cepedianum are met with sediment bacterial and algal biomass. Aquat Biol 8:105-114

> Smoot JC, Findlay RH (2010b) Microbes as food for sedimentingesting detritivores: low-density particles confer a nutritional advantage. Aquat Microb Ecol 59:103-109

Sutherland K (2008) Filters and filtration handbook, 5th edn. Butterworth-Heinemann, Oxford

Vanni MJ (2002) Nutrient cycling by animals in freshwater ecosystems. Annu Rev Ecol Syst 33:341-370

Vanni MJ, Arend KK, Bremigan MT, Bunnell DB and others (2005) Linking landscapes and food webs: effects of omnivorous fish and watersheds on reservoir ecosystems. Bioscience 55:155-167

Submitted: January 11, 2012; Accepted: August 20, 2012 Proofs received from author(s): October 29, 2012 